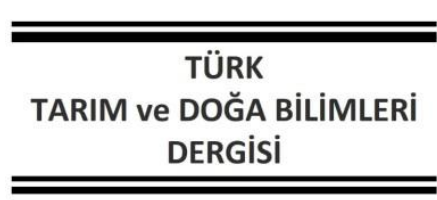

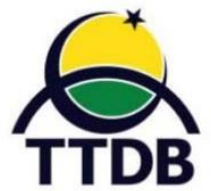

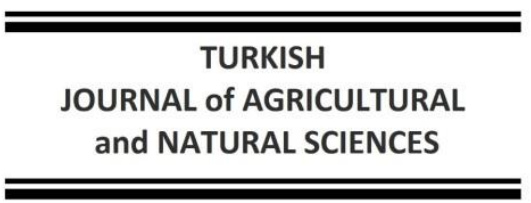

www.dergipark.gov.tr/turkjans

Research Paper

\title{
Determining the Selection Criteria for Grain Yield of Cluster Bean in Mediterranean Conditions
}

\author{
Rukiye KARA ${ }^{1 *}$, Mevlüt AKÇURA ${ }^{2}$ \\ ${ }^{1}$ East Mediterranean Transitional Zone Agricultural Research of Institute, 46100 \\ Kahramanmaras, Turkey \\ ${ }^{2}$ Department of Field Crops, Faculty of Agriculture, Canakkale Onsekiz Mart University, \\ Çanakkale, Turkey \\ *Corresponding Author: rkara46@gmail.com
}

Received: 14.09.2021 Received in revised: 29.09.2021 Accepted: 13.10.2021

\begin{abstract}
Due to its versatile usage area, cluster bean is one of the crops on which many adaptation studies have been carried out in different countries in recent years. This research was conducted to determine selection criteria to increase the grain yield in the different locations of the Mediterranean climate in Turkey. The research was established in four different locations with nine cluster bean genotypes with three replications in a $9 \times 10$ rectangular lattice experimental design. Seventeen quantitative traits were examined. Correlation, factor, biplot, regression, and path analysis were used to create selection criteria to select genotypes with high grain yields in cluster beans. According to correlation analysis, there were positive and significant correlations between grain yield and number of pods per plant (NPP), the number of seeds per plant (NSP), grain yield per plant (GYP), number of clusters per plant (NCP), the $45^{\text {th }}$-day of plant height $(45 \mathrm{PH}), 90^{\text {th }}$-day of plant height (90PH). Significant negative correlations were found between grain yield and pod width (WP), pod length (LP), and the number of grains per pod (NGP). According to the results of both factor and biplot analysis, seventeen traits were reduced to four factors, and factors explained $78.25 \%$ of the total variation. The most important factor group was composed of NPP, GY, NSP, NCP, and GYP with an explanation rate of $38.81 \%$. Path analysis explained $76 \%$ of the grain yield. This method showed that the plant grain yield $(P=0.81)$ and the number of clusters in the plant $(P=0.25)$ had the highest direct effect on grain yield. Regression analysis results were also like path analysis. In the regression analysis were grain yield was the dependent variable, the plant grain yield (10.811) and the number of clusters in the plant (3.11) had the highest B value. The total disclosure rate of these two traits in Collinearity statistics was $93 \%$. The results of all methods indicated that in the breeding programs to be established to increase the grain yield of cluster bean in the Mediterranean climate, selection on the seed yield of the plant and the number of pods in the cluster directly, according to the number of clusters in the plant indirectly will enable the breeders to reach their goals.
\end{abstract}

Keywords: Cluster bean, biplot, correlation, path, factor, selection

\section{Akdeniz Koşullarında Sakız Fasulyesinde Tane Verimi için Seleksiyon Kriterlerinin Belirlenmesi}

\section{$\ddot{\text { Öz }}$}

Sakız fasulyesi çok yönlü kullanım alanına sahip olmasından dolayı son yıllarda farklı ülkelerde en fazla adaptasyon çalışması yürütülen bitkilerdendir. Bu araştırma Akdeniz ikliminin hâkim olduğu Türkiye'nin farklı çevrelerinde sakız fasulyesinde tane verimini artırmak için seleksiyon kriteri oluşturmak amacıyla yürütülmüştür. Araştırma 90 sakız fasulyesi genotipi ile 9x10 latis deneme deseninde 3 tekerrürlü olarak dört faklı çevrede kurulmuş, 17 adet kantitatif özellik incelenmiştir. Sakız fasulyesinde yüksek tane verimine sahip olan genotipleri seçebilmek için seleksiyon kriteri oluşturmak amacıyla, korelasyon, faktör, biplot, regresyon ve 
path analizleri kullanılmıştır. Korelasyon analizine göre tane verimi ile bitkide bakla sayısı (NPP), bitkide tane sayısı (NSP), bitkide tane verimi (GYP), bitkide küme sayısı (NCP), 45. gün bitki boyu (45PH), 90. gün bitki boyu (90PH) arasında olumlu ve önemli, tane verimi ile bakla eni (WP), bakla boyu (LP) ve baklada tane sayısı (NGP) arasında ise olumsuz önemli korelasyonlar tespit edilmiştir. Faktör ve biplot analizi sonuçlarına göre 17 adet özellik dört faktöre indirgenmiş, faktörler toplam varyasyonun \% 78.25'ini açıklamıştır. En önemli faktör grubu \%38.81'lik açıklama oranı ile NPP, GY, NSP, NCP ve GYP den oluşmuştur. Path analizi tane veriminin \% 76 sını açıklamıştır. $B u$ yönteme göre tane verimi üzerine en yüksek doğrudan etkiye bitki tane verimi $(P=0.81)$ ve bitkide küme sayısı ( $\mathrm{P}=0.25)$ sahip olmuştur. Regresyon analizi sonuçları da path analizine benzer olmuştur. Tane veriminin bağımlı değişken olduğu regresyon analizinde en yüksek B değerine bitki tane verimi (10.811) ve bitkide küme sayısı (3.11) sahip olmuştur. Söz konusu iki özelliğin eş doğrusallık istatistikleri açıklama oranı toplamı \% 93 olarak gerçekleşmiştir. Tüm yöntemlerin sonuçlarına göre akdeniz ikliminin hüküm sürdüğü bölgelerde sakız fasulyesinde tane verimini artırmak amacıyla oluşturulacak ıslah programlarında öncelikle doğrudan bitki tane verimi ve bitkide küme sayısına göre dolaylı yönden ise kümede bakla sayısı üzerinden seleksiyon yapılması ıslahçıların hedefine ulaşmalarını sağlayacaktır.

Anahtar Kelimeler: Sakız fasulyesi, biplot, korelasyon, path, faktör, seleksiyon

\section{Introduction}

Cluster bean [Cyamopsis tetragonoloba (L.)

Taub.] is a one-year tropical legume. In India, guar is grown as livestock feed, vegetables (boiled and salted fresh beans), and industrial plants and is used in Indian traditional and modern medicine (Singh and Devi, 2016). Unlike other legumes, guar gum containing galactomannan obtained from the endosperm of its seeds has a special value and is widely used in the food, cosmetics, textile, paper, and oil industries. Due to many areas of use of cluster bean, it is one of the most studied plants in different environments in recent years. In some of these studies, researchers create breeding programs for their own countries (eg the USA), while in some other countries prefer to grow varieties originating from India and Pakistan by introduction.

Although the purpose of cluster bean breeding varies according to the purpose of use, it is to improve the grain yield and gum quality.However, both grain yield and gum quality of cluster bean are the results of the influence of many traits. For this reason, knowing which trait affects how and to what extent the grain yield increases the chance of success in breeding studies. In studies conducted with cluster beans, many traits are generally examined besides grain yield (Girish, et al., 2012; Vir and Singh, 2015; Manivannan et al., 2016). In this case, relationships that are difficult to interpret are encountered by researchers due to the interactions between many characters. Until now, researchers have generally preferred correlation and path analysis to interpret the relationships between these traits in cluster beans (Boghara et al., 2016; Gresta et al., 2018; Nampelli et al., 2020; Dadheech et al., 2020). However, both analysis methods reveal very complex data matrices when many traits are examined, and as a result, it makes it difficult to evaluate the results (Akçura et al., 2004). To eliminate these negativities, factor analysis was developed, the main element of which is to group the characters that have significant binary relationships among themselves (Walton, 1971). For this purpose, factor analysis has been used by researchers to group different characters in different plants (Cagirgan and Yildirim, 1990; Akçura et al., 2004; Toker 2004; Canci and Toker, 2009). Similarly, biplot analysis was used to create selection criteria over complex properties in different plants (Yan and Rajcan, 2002; Yan and Reid, 2018; Papastylianou et al., 2021; Khan et al., 2021; Aktaş and Ure, 2021)

The objectives of this study were to create a selection criterion of cluster bean where was grown in a different environment dominated by Turkey's Mediterranean climate using different statistical methods to achieve the highest grain yield production.

\section{Materials and Methods}

As plant material, registered four cultivars (Guajarat, Haryana, Pusa Nevbahar, and Samen) of Indian and Pakistan, and 86 advanced lines have been developed in Turkey were used in the study.

The experiments were established in 2017 in Çanakkale, Bandırma, Burhaniye, and İzmir locations with 3 replications according to a $9 \times 10$ rectangular lattice trial design. Some information about the trials was given in Tables 1 and 2 . Soil samples were taken at a depth of $0-30 \mathrm{~cm}$ from the trial fields before sowing. Trial fields generally have low organic matter content, neutral and slightly alkaline soil reactions. The plot area in the trials was $4 \mathrm{~m}^{2}(2 \mathrm{~m} \times 2 \mathrm{~m})$. The plots were set up to consist of 4 rows, the distance between the rows is $50 \mathrm{~cm}$, and the distance within the row is $10 \mathrm{~cm}$. Seeds were sown by hand, 3 seeds in each $10 \mathrm{~cm}$ were planted in a depth of $2-4 \mathrm{~cm}$ in a quarry. The 
number of plants in each seedbed was reduced to one by pulling after the emergence. A $1 \mathrm{~m}$ distance was left between the blocks in each location. In the experiments, approximately $3 \mathrm{~kg} \mathrm{da}^{-1}$ pure nitrogen and $6 \mathrm{~kg} / \mathrm{da}$ phosphorus were given as the base fertilizer at sowing. An additional $3 \mathrm{~kg} \mathrm{da}^{-1}$ of nitrogen was applied at the beginning of the flowering stage. Weeds were controlled by herbicides licensed for beans before sowing (herbicide with Benfluralin active ingredient) and after emergence (herbicide with Bentazone active ingredient). Harvesting operations were done manually at each location, and threshing operations were done with a plot threshing machine.

Table 1. Some information about the trials

\begin{tabular}{|c|c|c|c|c|}
\hline Locations & Sowing date & $\begin{array}{l}\text { Number of } \\
\text { irrigations }\end{array}$ & $\begin{array}{c}\text { Hoeing } \\
\text { operation }\end{array}$ & Harvest date \\
\hline Bandırma & 7.05 .2017 & 5 & 1 & $05-06.10 .2017$ \\
\hline Burhaniye & 30.04 .2017 & 7 & 2 & 01-03.10.2017 \\
\hline Çanakkale & 5.05 .2017 & 6 & 2 & $10-14.10 .2017$ \\
\hline İzmir & 23.04.2017 & 5 & 1 & 26.09 .2017 \\
\hline
\end{tabular}

The sowing process was carried out at the end of April in Izmir and Burhaniye locations and in May in Çanakkale and Bandırma locations. Depending on the location the highest temperature in this month was around $30^{\circ} \mathrm{C}$, (Table 3). However, significant differences occurred at the lowest temperatures affecting the adaptation of genotypes based on locations.

In the study, the 45th-day plant height (45PH), 90th-day plant height (90PH), plant height
$(\mathrm{PH})$, stem thickness (SD), flowering initiation time (DIF), flowering time (DF), physiological maturity time (MF), number of clusters per plant (NCP), cluster length (LC), number of pods per cluster (NPC), pod length (LP), pod width (WP), number of pod per plant (NPP), number of seed per pod (NSP), plant grain yield (GYP) ), grain yield (GY), number of grain per plant (NGP) were recorded.

Table 2. Some soil properties of the trial sites ( $30 \mathrm{~cm}$ depth)

\begin{tabular}{lllccccc}
\hline & \multicolumn{7}{c}{ Properties } \\
\cline { 2 - 8 } Locations & Soil group & $\mathrm{PH}$ & $\mathrm{S}(\%)$ & $\mathrm{OM}(\%)$ & $\mathrm{CaCO}_{3}(\%)$ & $\mathrm{K}(\mathrm{kg} / \mathrm{da})$ & $\mathrm{P}(\mathrm{kg} / \mathrm{da})$ \\
\hline Bandırma & Loamy & 7.72 & 40.7 & 2.85 & 6.3 & 277 & 17.16 \\
Burhaniye & Sandy loamy & 7.2 & 37 & 1.00 & 15 & 28 & 10 \\
Çanakkale & Clayey-loamy & 8.15 & 55 & 1.34 & 11.2 & 67.48 & 2.13 \\
İzmir & Loamy & 7.0 & 50.6 & 1.11 & 2.4 & 161 & 16.49 \\
\hline
\end{tabular}

Pearson's correlation method was used to determine the binary correlation coefficient $(r)$ values between the traits in the study. Both Factor and biplot analysis was performed to collect the 17 traits that have significant correlation coefficients among themselves under a group and reduce them to a smaller number of variables. In the factor analysis, first, the mean and standard deviations of the traits were calculated, and the correlation matrix was created, and then the factor loadings matrix was estimated. Factor matrix and common variance values were obtained by applying varimax rotation to the factor loadings matrix. Besides, the contribution of each factor to the total variance was expressed as a percentage, and the sign of the factor loadings within the same factor was interpreted as the direction of the relationship between the relevant traits (Akçura et al., 2004). On the other hand, biplot analysis was carried out to visually evaluate the groups formed in the factor analysis. Path analysis was conducted to determine the direct and indirect effects of the traits in the same factor group with the grain yield (Kang, 2015). Also, both heritability of the evaluated traits and multiple regression analyzes of the traits of the grain yield factor were performed (Holland et al., 2003). Correlation, factor, path, and regression analysis and heritability were computed using the SAS statistical package program (SAS institute 1999). Biplot analysis was performed using the GGE biplot Gui module in the R package ( $R$ Core Team 2016). 
Table 3. Some climatic data from locations

\begin{tabular}{|c|c|c|c|c|c|c|c|}
\hline \multirow{2}{*}{ Climates } & April & May & June & July & August & September & October \\
\hline & \multicolumn{7}{|c|}{ Bandırma } \\
\hline $\operatorname{Max}\left({ }^{\circ} \mathrm{C}\right)$ & 27.4 & 33.1 & 36.4 & 36.4 & 32.5 & 39 & 28.5 \\
\hline $\operatorname{Min}\left({ }^{\circ} \mathrm{C}\right)$ & 1.7 & 7.4 & 14.1 & 16.5 & 17.1 & 10.7 & 6.2 \\
\hline Mean $\left({ }^{\circ} \mathrm{C}\right)$ & 12 & 17.1 & 22.6 & 24.4 & 24.7 & 22.3 & 15.1 \\
\hline Humidity(\%) & 66.1 & 70.7 & 67.7 & 67.1 & 72.8 & 63 & 74 \\
\hline $\begin{array}{l}\text { Rainfall } \\
\left(\mathrm{kg} / \mathrm{m}^{2}\right)\end{array}$ & 24 & 28.8 & 18.8 & 25.4 & 9 & 26.4 & 24.4 \\
\hline \multicolumn{8}{|c|}{ Burhaniye } \\
\hline $\operatorname{Max}\left({ }^{\circ} \mathrm{C}\right)$ & 29.2 & 31.5 & 39.4 & 43.2 & 38.2 & 35.9 & 29.1 \\
\hline $\operatorname{Min}\left({ }^{\circ} \mathrm{C}\right)$ & 2.7 & 8.5 & 14.3 & 16.4 & 18 & 10.2 & 6.2 \\
\hline Mean $\left({ }^{\circ} \mathrm{C}\right)$ & 14.7 & 20 & 25.1 & 27.5 & 27.7 & 23.2 & 17.3 \\
\hline Humidity(\%) & 56.3 & 55.7 & 52.5 & 45.6 & 48.5 & 49.3 & 56.9 \\
\hline $\begin{array}{l}\text { Rainfall } \\
\left(\mathrm{kg} / \mathrm{m}^{2}\right)\end{array}$ & 16.8 & 13 & 15.2 & 25.8 & 0.6 & 10 & 31 \\
\hline \multicolumn{8}{|c|}{ Çanakkale } \\
\hline $\operatorname{Max}\left({ }^{\circ} \mathrm{C}\right)$ & 18.9 & 23.9 & 29.9 & 32.6 & 32.3 & 27.3 & 20.6 \\
\hline $\operatorname{Min}\left({ }^{\circ} \mathrm{C}\right)$ & 8.2 & 14 & 19 & 21.1 & 21.8 & 16.9 & 10.5 \\
\hline Mean $\left({ }^{\circ} \mathrm{C}\right)$ & 12.8 & 17.0 & 22 & 24 & 25 & 20 & 15 \\
\hline Humidity(\%) & 62.2 & 65.5 & 62 & 55.7 & 54.9 & 57.6 & 67.5 \\
\hline $\begin{array}{l}\text { Rainfall } \\
\left(\mathrm{kg} / \mathrm{m}^{2}\right)\end{array}$ & 14.9 & 19.3 & 36.8 & 17.2 & 0 & 11.7 & 58.3 \\
\hline \multicolumn{8}{|c|}{ İzmir } \\
\hline $\operatorname{Max}\left({ }^{\circ} \mathrm{C}\right)$ & 31.5 & 35 & 45.2 & 45.6 & 40.8 & 38.8 & 30.3 \\
\hline $\operatorname{Min}\left({ }^{\circ} \mathrm{C}\right)$ & 3.6 & 9.8 & 13.3 & 15.7 & 17.2 & 10.4 & 6.5 \\
\hline Mean $\left({ }^{\circ} \mathrm{C}\right)$ & 16 & 21.2 & 26 & 29.8 & 29.5 & 24.1 & 17.8 \\
\hline Humidity(\%) & 65.5 & 59.6 & 57 & 44.7 & 48.8 & 54.8 & 64.9 \\
\hline $\begin{array}{l}\text { Rainfall } \\
\left(\mathrm{kg} / \mathrm{m}^{2}\right)\end{array}$ & 56.8 & 18.1 & 44.7 & 0 & 2.8 & 1.2 & 43.5 \\
\hline
\end{tabular}

\section{Results}

Seventeen traits were examined in the trials established according to the rectangular lattice experiment design with ninety cluster bean genotypes at four different locations. Differences between genotypes were found to be statistically significant in terms of all traits across trials. The heritability levels of the traits across locations were given in Table 4. Also, correlation (Table 4), factor (Table 5), biplot (Figure 1), path (Table 6), and regression (Table 7) analyzes were performed across experimental mean to determine the traits that can be used to obtain high grain yield in cluster bean.

\section{Descriptive Statistics and Heritability}

Significant variation was detected in all locations of all traits examined except PW. Among the experimental locations, İzmir had the highest values in terms of properties such as GY, PH, NPP,
NSP, and PGY. The lowest values in terms of the investigated traits were measured mostly in the Bandırma location (Data not given). The heritability of the traits determined across locations varied between $8 \%$ and $96 \%$. The highest heritability was obtained from NPP, GY, and DIF traits of $96 \%, 95 \%$, and $93 \%$, respectively.

\section{Correlation analysis}

Of the 136 correlation coefficients calculated for all traits, thirty-eight coefficients were positively significant, twenty-eight coefficients were negatively significant, and the others were found statistically insignificant. Positive and significant correlations were found between grain yield and NPP, NSP, GYP, NCP, $45 \mathrm{PH}, 90 \mathrm{PH}$, and negative and significant correlations between grain yield and WP, LP, and NGP (Table 4). 
Türk Tarım ve Doğa Bilimleri Dergisi 8(4): 983-994, 2021

Table 4. Heritability and heat map created with the correlation coefficients of the investigated traits $(n=270)$.

\begin{tabular}{|c|c|c|c|c|c|c|c|c|c|c|c|c|c|c|c|c|c|c|}
\hline & $45 \mathrm{PH}$ & $90 \mathrm{PH}$ & $\mathrm{PH}$ & SD & DIF & DF & $\mathrm{MF}$ & $\mathrm{NCP}$ & LC & NPC & LP & WP & NPP & NSP & GYP & GY & NGP & $\begin{array}{c}\text { Heritability } \\
(\%)\end{array}$ \\
\hline $45 \mathrm{PH}$ & & 0.97 & 0.92 & 0.63 & -0.07 & 0.11 & 0.21 & 0.33 & 0.25 & -0.13 & -0.51 & -0.45 & 0.46 & 0.51 & 0.59 & 0.64 & -0.46 & 59.0 \\
\hline $90 \mathrm{PH}$ & 0.97 & & 0.92 & 0.63 & -0.04 & 0.07 & 0.21 & 0.37 & 0.27 & -0.11 & -0.56 & -0.53 & 0.51 & 0.55 & 0.62 & 0.68 & -0.50 & 57.0 \\
\hline $\mathrm{PH}$ & 0.92 & 0.92 & & 0.61 & -0.04 & 0.24 & 0.36 & 0.14 & 0.32 & -0.05 & -0.20 & -0.22 & 0.23 & 0.28 & 0.49 & 0.40 & -0.18 & 36.0 \\
\hline SD & 0.63 & 0.63 & 0.61 & & 0.14 & 0.14 & 0.47 & 0.11 & 0.38 & 0.00 & -0.31 & -0.24 & 0.24 & 0.26 & 0.40 & 0.39 & -0.33 & 21.0 \\
\hline DIF & -0.07 & -0.04 & -0.04 & 0.14 & & -0.68 & 0.27 & 0.16 & -0.08 & -0.14 & 0.02 & -0.03 & 0.11 & 0.07 & 0.07 & 0.05 & 0.00 & 93.0 \\
\hline DF & 0.11 & 0.07 & 0.24 & 0.14 & -0.68 & & 0.50 & -0.36 & 0.15 & 0.18 & 0.32 & 0.24 & -0.31 & -0.29 & -0.06 & -0.24 & 0.22 & 61.0 \\
\hline $\mathrm{MF}$ & 0.21 & 0.21 & 0.36 & 0.47 & 0.27 & 0.50 & & -0.14 & 0.12 & 0.03 & 0.21 & 0.08 & -0.10 & -0.12 & 0.14 & -0.04 & 0.09 & 39.0 \\
\hline $\mathrm{NCP}$ & 0.33 & 0.37 & 0.14 & 0.11 & 0.16 & -0.36 & -0.14 & & -0.05 & -0.55 & -0.66 & -0.62 & 0.88 & 0.79 & 0.57 & 0.66 & -0.61 & 70.0 \\
\hline LC & 0.25 & 0.27 & 0.32 & 0.38 & -0.08 & 0.15 & 0.12 & -0.05 & & 0.05 & -0.04 & -0.06 & -0.01 & 0.06 & 0.19 & 0.11 & 0.04 & 63.0 \\
\hline NPC & -0.13 & -0.11 & -0.05 & 0.00 & -0.14 & 0.18 & 0.03 & -0.55 & 0.05 & & 0.20 & 0.28 & -0.32 & -0.22 & -0.18 & -0.24 & 0.17 & 8.0 \\
\hline LP & -0.51 & -0.56 & -0.20 & -0.31 & 0.02 & 0.32 & 0.21 & -0.66 & -0.04 & 0.20 & & 0.85 & -0.80 & -0.78 & -0.53 & -0.85 & 0.88 & 74.0 \\
\hline WP & -0.45 & -0.53 & -0.22 & -0.24 & -0.03 & 0.24 & 0.08 & -0.62 & -0.06 & 0.28 & 0.85 & & -0.72 & -0.69 & -0.51 & -0.78 & 0.73 & 88.0 \\
\hline NPP & 0.46 & 0.51 & 0.23 & 0.24 & 0.11 & -0.31 & -0.10 & 0.88 & -0.01 & -0.32 & -0.80 & -0.72 & & 0.94 & 0.73 & 0.80 & -0.72 & 96.0 \\
\hline NSP & 0.51 & 0.55 & 0.28 & 0.26 & 0.07 & -0.29 & -0.12 & 0.79 & 0.06 & -0.22 & -0.78 & -0.69 & 0.94 & & 0.76 & 0.82 & -0.60 & 85.0 \\
\hline GYP & 0.59 & 0.62 & 0.49 & 0.40 & 0.07 & -0.06 & 0.14 & 0.57 & 0.19 & -0.18 & -0.53 & -0.51 & 0.73 & 0.76 & & 0.78 & -0.45 & 82.0 \\
\hline GY & 0.64 & 0.68 & 0.40 & 0.39 & 0.05 & -0.24 & -0.04 & 0.66 & 0.11 & -0.24 & -0.85 & -0.78 & 0.80 & 0.82 & 0.78 & & -0.74 & 95.0 \\
\hline NGP & -0.46 & -0.50 & -0.18 & -0.33 & 0.00 & 0.22 & 0.09 & -0.61 & 0.04 & 0.17 & 0.88 & 0.73 & -0.72 & -0.60 & -0.45 & -0.74 & & 96.0 \\
\hline
\end{tabular}

Correlations coefficients

1.00

45PH: the 45th-day plant height $(\mathrm{cm}), 90 \mathrm{PH}$ : 90th-day plant height $(\mathrm{cm}), \mathrm{PH}$ : plant height $(\mathrm{cm}), \mathrm{SD}$ : stem thickness (mm), DIF: flowering initiation time (day), DF: flowering time (day), MF: physiological maturity time (day), NCP: number of clusters per plant (number), LC: cluster length (cm), NPC: number of pods per cluster (number), LP: pod length (cm), WP: pod width (cm), NPP: number of pod per plant (number), NSP: number of seed per pod (number), GYP: plant grain yield (g plant-1), GY: grain yield (kg da-1), NGP: number of grain per plant (number) 


\section{Factor and Biplot Analysis}

The seventeen characters used in this study were reduced to four-factor groups by factor analysis. In Table 5, factors, common variances, factor loadings, and values of each factor in total variance were given. The biplot created to evaluate the factors visually was given in Figure 1.

Four factors calculated according to factor analysis results explained $78.25 \%$ of the total variation. The shares for each factor were $38.81 \%$, $22.15 \%, 9.94 \%$, and 7.34, respectively. Common variance values varied between 0.654 and 0.979 . The highest common variance values were obtained from the flowering initiation time (0.979) and the flowering time (0.920), while the lowest common variance value was obtained from the plant grain yield $(0.654)$ and the number of pods in the cluster (0.687).
When the factors are examined separately; Factor 1 has the highest share with $38.81 \%$ in the total variation. Factor 1; Consists of NPP, GY, NSP, $\mathrm{NCP}$, and GYP. All of the traits in this factor group have positive load values. NPP (0.9035) and GY $(0.880)$ had the highest factor loadings. The share of factor 2 in total variance was $22.75 \%$. Factor 2 consisted of $\mathrm{PH}, \mathrm{SD}, 45 \mathrm{PH}, 90 \mathrm{PH}$, and MF. All characters in this factor group had a positive load value. Plant height $(0.882)$ and stem diameter $(0.810)$ had the highest factor loadings. Factor 3 explained $9.94 \%$ of the total variance. This factor constituted the flowering time and the flowering initiation time. Factor 4 consisted of NPC, LC, LP, WP, and NSP. This factor made up $7.34 \%$ of the total variation.

Table 5. Grouping of seventeen features with factor analysis $(n=270)$

\begin{tabular}{|c|c|c|c|c|c|}
\hline Traits & Factor 1 & Factor 2 & Factor 3 & Factor 4 & Communality \\
\hline NPP & 0.903 & 0.097 & 0.103 & -0.239 & 0.892 \\
\hline GY & 0.880 & 0.306 & 0.050 & -0.048 & 0.873 \\
\hline NSP & 0.879 & 0.155 & 0.083 & -0.131 & 0.820 \\
\hline NCP & 0.791 & -0.036 & 0.140 & -0.463 & 0.861 \\
\hline GYP & 0.647 & 0.443 & 0.020 & -0.198 & 0.654 \\
\hline $\mathrm{PH}$ & 0.195 & 0.882 & -0.135 & -0.027 & 0.835 \\
\hline SD & 0.177 & 0.810 & 0.122 & 0.051 & 0.705 \\
\hline $45 \mathrm{PH}$ & 0.491 & 0.777 & -0.129 & 0.001 & 0.862 \\
\hline $90 \mathrm{PH}$ & 0.539 & 0.773 & -0.102 & 0.022 & 0.899 \\
\hline MF & -0.340 & 0.648 & 0.048 & -0.401 & 0.699 \\
\hline DF & -0.366 & 0.336 & -0.810 & -0.130 & 0.920 \\
\hline DIF & -0.054 & 0.109 & 0.962 & -0.197 & 0.979 \\
\hline NPC & -0.270 & 0.075 & -0.064 & 0.777 & 0.687 \\
\hline LC & -0.004 & 0.472 & -0.034 & 0.284 & 0.305 \\
\hline LP & -0.096 & -0.092 & -0.034 & -0.937 & 0.896 \\
\hline WP & 0.047 & -0.113 & -0.022 & -0.840 & 0.722 \\
\hline NSP & -0.041 & -0.108 & -0.011 & -0.825 & 0.695 \\
\hline Variance & 6.60 & 3.77 & 1.69 & 1.25 & \\
\hline Percent & 38.81 & 22.15 & 9.94 & 7.34 & \\
\hline Cum Percent & 38.81 & 60.96 & 70.91 & 78.25 & \\
\hline
\end{tabular}

45PH: the 45th-day plant height $(\mathrm{cm}), 90 \mathrm{PH}:$ 90th-day plant height $(\mathrm{cm}), \mathrm{PH}$ : plant height $(\mathrm{cm})$, SD: stem thickness $(\mathrm{mm})$, DIF: flowering initiation time (day), DF: flowering time (day), MF: physiological maturity time (day), NCP: number of clusters per plant (number), LC: cluster length (cm), NPC: number of pods per cluster (number), LP: pod length (cm), WP: pod width $(\mathrm{cm})$, NPP: number of pod per plant (number), NSP: number of seed per pod (number), GYP: plant grain yield (g plant $\left.{ }^{-1}\right), \mathrm{GY}^{\mathrm{N}}$ grain yield $\left(\mathrm{kg} \mathrm{da}^{-1}\right)$, NGP: number of grain per plant (number)

\section{Path Analyses}

Path analysis was performed for a more detailed examination of the effects of characters (NPP, NSP, NCP, and GYP) in the same factor group with grain yield on $\mathrm{GY}$ and the results are given in Table 6 and Figure 2.

Path analysis explained $76 \%$ of the grain yield. Within the positive and important correlation coefficient between grain yield and plant grain yield, the direct effect of plant grain yield on grain yield (Ps11 $=0.81$ ) was $70 \%$. The indirect effect of this trait on the grain yield over the number of pods per plant was $18 \%$.

As seen in Table 6, the direct effect of the number of pods per plant $(P=-0.62)$ in the positive and important correlation coefficient between the number of pods in the plant and the grain yield was negative at a rate of $33.0 \%$. The positive 
indirect effect of the number of pods per plant on the grain yield in the plant was $42 \%$.

Within the positive and important correlation coefficient between the grain yield and the number of clusters, the direct effect $(P=0.25)$ of the mentioned trait was positive at a rate of $29 \%$, and the indirect effect on the number of pods per plant $(P=-0.29)$ was $34 \%$ negatively.

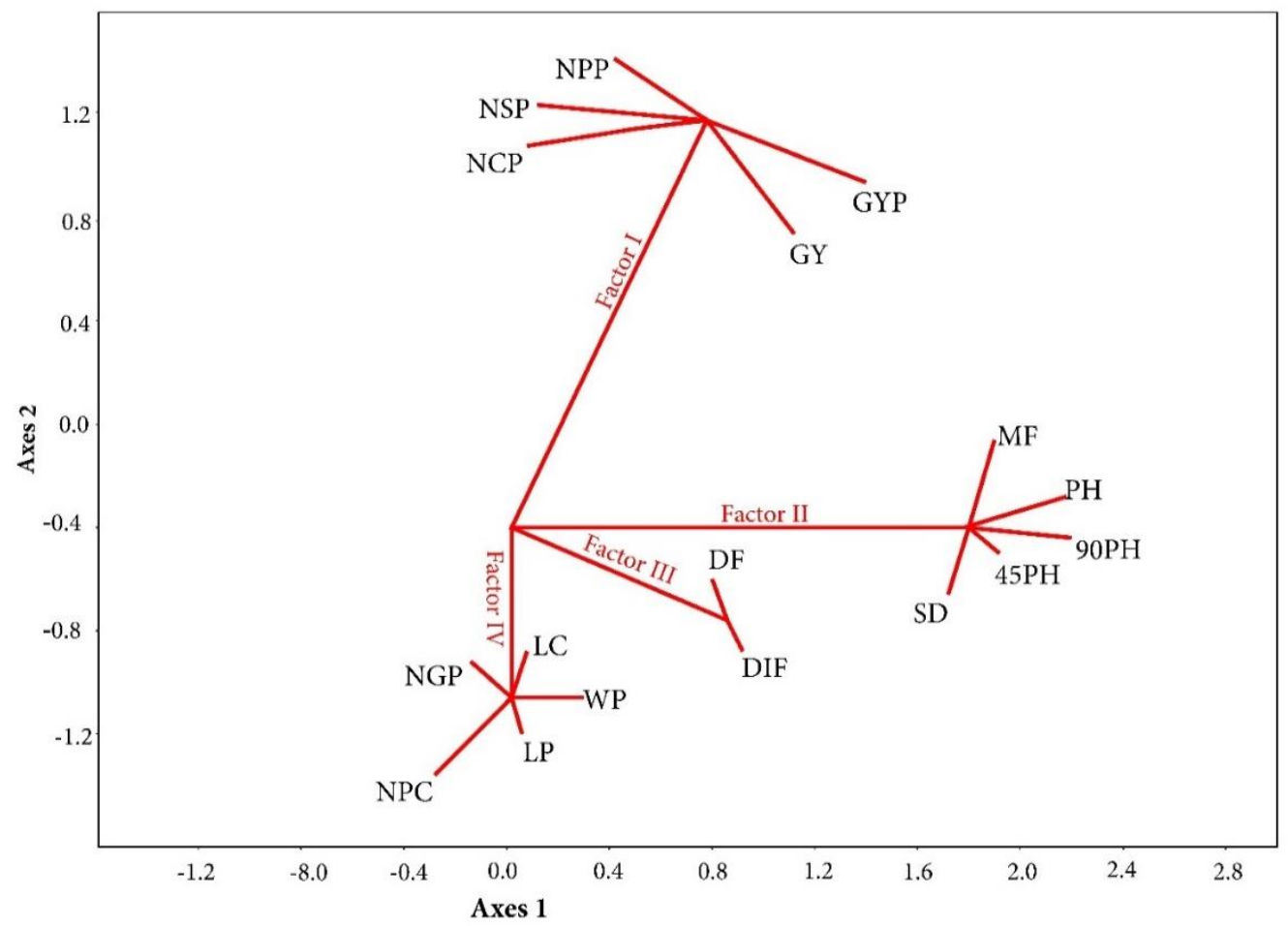

Figure 1. Biplot of groups formed by features according to factors ( $n=270$ )

\section{Regression analysis}

Table 7 showed the results of multiple regression analysis, where grain yield was the dependent variable, and the independent variables were the traits of factor 1 . According to the results of the regression analysis, the traits that have the highest positive and significant effect on the grain yield were the plant grain yield and the number of clusters in the plant, while the negative and significant effect was the number of pods per plant.

\section{Discussion}

Cluster bean is one of the crops with many different use areas (Akcura et al., 2019). Due to its different usage areas, intensive research is carried out on its cultivation in different geographic regions of the world. Cluster bean is a new crop for Mediterranean countries. Thus, the number of research on cluster bean cultivation in Mediterranean countries is very low. In few studies, it has been determined that the summer temperatures in Mediterranean countries are above $30^{\circ} \mathrm{C}$ temperatures with extreme conditions which are not suitable for the cultivation of many plants, are very suitable environments for cluster bean cultivation (Gresta et al., 2016a; Gresta et al.,
2018; Santonoceto et al., 2019). However, varieties developed in different countries were used in the studies. This research in the cluster bean has been used four kinds of beans and 86 genotypes that have been developed in Turkey. It was aimed to create a selection criterion specifically for the Mediterranean environment, based on 17 plant traits examined in experiments grown in different environments. For this purpose, the most widely used multivariate techniques were used.

The heritability level calculated in the experiments established in different environments expresses the extent to which the examined trait emerges from the genotype effect and the environmental effect (Akçura, 2009). In this study, the characteristics that were the most affected by the environment and the lowest heritability were NPC, SD, and PH. The traits that were least affected by the environment and had the highest heritability were the NGP, NPP, GY, and DIF traits. Especially the high heritability of the traits that have positive and important relationships with grain yield. Also, grain yield showed that the genotypes included in the experiment adapted well to the Mediterranean environment. 
Table 6. Path analysis results of the properties in the grain yield factor over the locations

\begin{tabular}{|c|c|c|}
\hline Traits & Effect values & The ratio in total (\%) \\
\hline \multicolumn{3}{|c|}{ Number of pods per plant (NPP) } \\
\hline Direct effect on GY & -0.36 & 0.33 \\
\hline \multicolumn{3}{|l|}{ Indirect effect } \\
\hline Number of grains per plant & 0.07 & 0.07 \\
\hline Grain yield per plant & 0.46 & 0.42 \\
\hline Number of clusters per plant & 0.20 & 0.18 \\
\hline \multicolumn{3}{|c|}{ Number of grains per plant (NGP) } \\
\hline Direct effect on GY & 0.08 & 0.08 \\
\hline \multicolumn{3}{|l|}{ Indirect effect } \\
\hline Number of pods per plant & -0.31 & 0.29 \\
\hline Grain yield per plant & 0.51 & 0.48 \\
\hline Number of clusters per plant & 0.15 & 0.14 \\
\hline \multicolumn{3}{|c|}{ Grain yield per plant (PGY) } \\
\hline Direct effect on GY & 0.81 & 0.70 \\
\hline \multicolumn{3}{|l|}{ Indirect effect } \\
\hline Number of pods per plant & -0.21 & 0.18 \\
\hline Number of grains per plant & 0.05 & 0.05 \\
\hline Number of clusters per plant & 0.08 & 0.07 \\
\hline \multicolumn{3}{|c|}{ Number of clusters per plant (NCP) } \\
\hline Direct effect on GY & 0.25 & 0.29 \\
\hline \multicolumn{3}{|l|}{ Indirect effect } \\
\hline Number of pods per plant & -0.29 & 0.33 \\
\hline Number of grains per plant & 0.05 & 0.06 \\
\hline Grain yield per plant & 0.27 & 0.31 \\
\hline
\end{tabular}




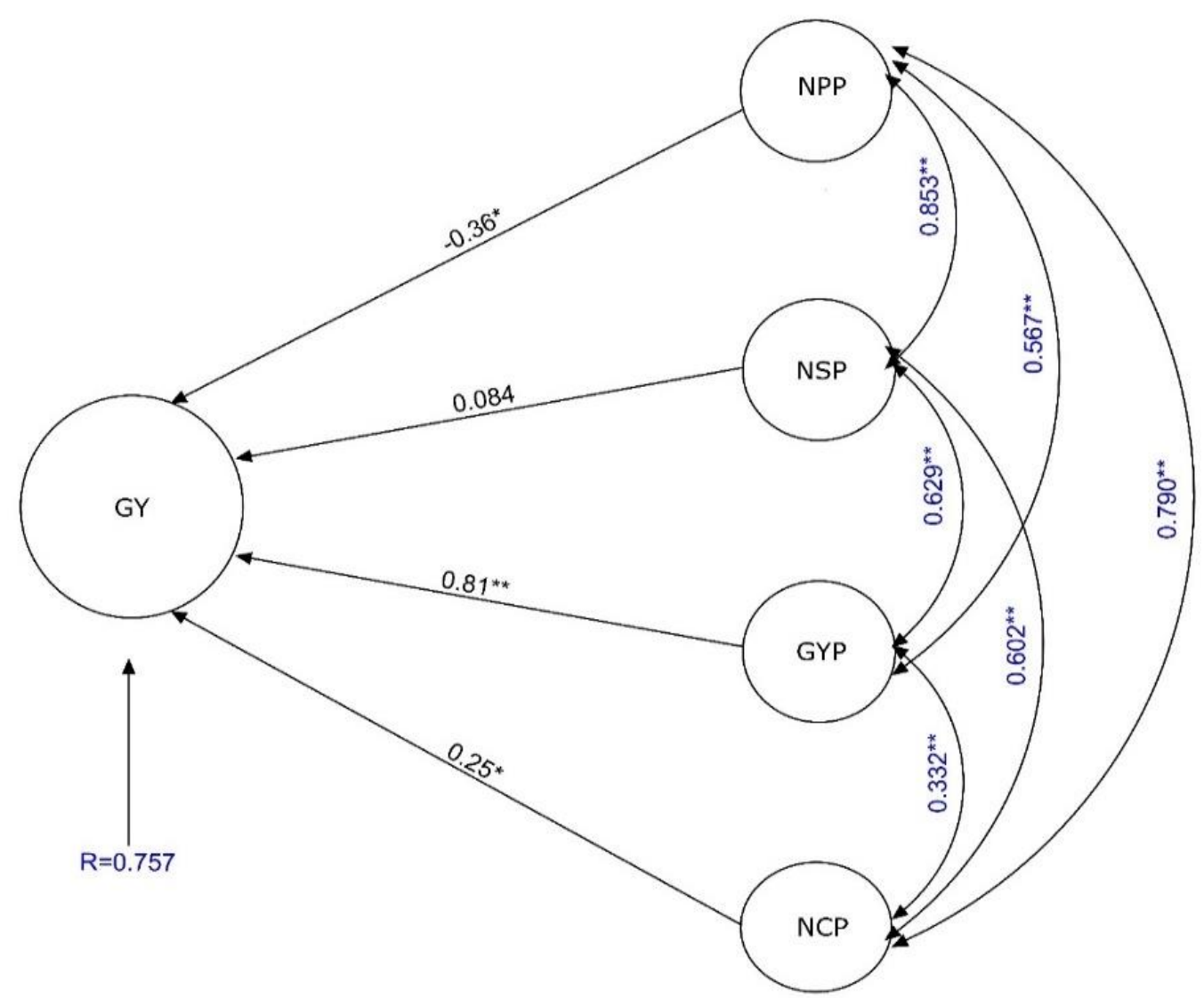

Figure 2. Path diagram of the properties in the same group with grain yield

Table 7. Multiple regression analysis results where grain yield is the dependent variable

\begin{tabular}{lcccccc}
\hline \multirow{2}{*}{ Traits } & \multicolumn{2}{c}{ Regression slope } & \multicolumn{2}{c}{ t-value } & \multicolumn{2}{c}{ Collinearity statistics } \\
\cline { 2 - 7 } & B & SE & Value & Prob. & VIF & TOL \\
\hline Number of clusters per plant & 3.110 & 1.599 & 1.945 & 0.046 & 2.884 & 0.347 \\
Number of pods per plant & -0.890 & 0.482 & -1.846 & 0.069 & 6.749 & 0.148 \\
Number of seeds per Plant & 0.036 & 0.067 & 0.538 & 0.592 & 4.249 & 0.235 \\
Grain yield per plant & 10.811 & 1.318 & 8.201 & 0.000 & 1.712 & 0.584 \\
\hline
\end{tabular}

Model $\mathrm{R}^{2}=60 \%$; SE: standard error; VIF: variance inflation factor

When looked at the relationship between grain yield and all examined properties, positive and significant correlations were found in NSP, NPP, GYP, 90PH, 45PH, NCP, PH, and SD properties, while negative and significant correlations were determined between LP, WP, and NGP. Meftahizadeh et al. (2019) determined positive and significant correlations between the GY and NPP, NPC, NCP NSP. Boghara et al. (2016) reported that the highest positive and significant correlations with plant grain yield are between the number of clusters per plant. Patak and Roy (2015) found the highest positive and important relationship between grain yield and NPP in their research, where they examined the relationship between different plant characteristics and grain yield in cluster bean. Sultan et al. (2012) determined that there was a positive and significant correlation between grain yield and the number of clusters per plant and the number of pods in the cluster. Besides, significant correlations were found between other investigated traits. For this reason, factor analysis was performed to evaluate all characteristics together and to interpret them more easily by reducing them to a smaller number of groups (Akçura et al., 2004, Canci and Toker, 2009). Factor analysis and trait grouping can be used in different environments in plants such as wheat (Jaradat, 2020), Chickpea (Gediya et al., 2019; Toker, 2004), rape (Cullis et al., 2010; Moradi et al., 2017). It was used to create selection criteria under conditions. In this study, seventeen traits examined in 90 cluster bean genotypes evaluated in different trials were reduced to four by factor analysis. Factor analysis explained $78.25 \%$ of the total variation. In the biplot created to visualize the groups in factor 
analysis, the first-factor group, which has the highest share among the factors, was composed of GY, GYP, NCP, NSP, and NPP with the longest vector length, and explained $38.81 \%$ of the total variance (Figure 1). Since the main purpose of our research was to determine the properties that will increase the GY, this factor was called the grain yield factor. Path analysis (Akçura et al., 2004) and multiple regression analysis (Jaradat, 2020) were performed to better explain the effect of the traits in the grain yield factor on the grain yield.

According to the path analysis results, while PGY, NCP, and NGP were the traits that increased the grain yield, the NPP decreased the GY. In the same analysis method, the NPP over the NGP, the NGP based on the PGY, and the NCP over the NPP also increased the GY. Multiple regression analysis results, where GY was the dependent variable, also confirmed the direct positive and negative associations in the path analysis. However, in the regression analysis, the properties that had been statistically significant positive effects the PGY, $N C P$, the negative effects of the NPP, and the positive effects of the NGP was found to be statistically negative.

\section{Conclusion}

As a result, seventeen traits examined with grain yield in nine cluster beans grown in four locations in the Mediterranean climate zone were evaluated to create selection criteria by correlation, factor, path, and multiple regression analysis. According to the common result of different methods, in breeding programs aiming to develop genotypes with high grain yield in cluster bean for Mediterranean climate conditions, genotypes with high plant grain yield and number of clusters in the plant should be selected. Also, if the number of pods per plant will be used as a selection in breeding programs of cluster bean, considering the number of seeds in the plant with this trait may contribute to the development of high grain yield varieties for Mediterranean climate conditions.

Conflict of Interest Statement: The author of the manuscript declares that there is no conflict of interest.

Contribution Rate Statement Summary: The writing of the article was performed by the author.

\section{Acknowledgments}

This research was funded by the Scientific and Technological Research Council of Turkey; Grant project number 1170068. We are grateful for the financial support of TUBITAK.

\section{References}

Akçura, M., 2009. Genetic variability and interrelationship among grain yield and some quality traits in Turkish winter durum wheat landraces. Turkish Journal of Agriculture and Forestry, 33: 547-556. https://doi.org/10.3906/tar-0903-5.

Akcura, M., Turan, V., Kokten, K., Kaplan, M. 2019. Fatty acid and some micro element compositions of cluster bean (Cyamopsis tetragonoloba) genotype seeds growing under Mediterranean climate. Industrial Crops and Products 128: 140-146. https://doi.org/10.1016/j.indcrop.2018.10.0 62.

Akçura, M., Dokuyucu, T., Kara, R., Akkaya, A., 2004. Ekmeklik Buğdayda (Triticum aestivum L.) Verim Karakterlerinin Çok Değişkenli Veri Analiz Yöntemleri İle Yorumlanması. Bitkisel Araştırma Dergisi, 1, 32-38.

Aktas, B., Ure, T., 2021. Evaluation of multienvironment grain yield trials in maize hybrids by GGE-biplot analysis method. Maydica, 65: 1-9.

Azizi, F., Rezaie A.M., Mir Mohammadi Meibodi A.M., 2001. Evaluation genetic and phenotypic variation and factor analysis on morphological traits in bean genotypes $J$. Science and Technology of Agriculture and Natural Resources, 5: 127-140.

Boghara, M. C., Dhaduk, H. L., Kumar, S., Parekh, M. J., Patel, N. J., Sharma, R., 2016. Genetic divergence, path analysis and molecular diversity analysis in cluster bean (Cyamopsis tetragonoloba L. Taub.). Industrial Crops and Products 89: 468-477. https://doi.org/10.1016/j.indcrop.2016.05.0 49.

Cagirgan, M.I., Yildirim, M.B., 1990. An application of factor analysis to data from control and macro mutant populations of Quantum barley. J. Fac. of Agric. of Akdeniz University, 4: 125- 138.

Canci, H., Toker, C., 2009. Evaluation of yield criteria for drought and heat resistance in chickpea (Cicer arietinum L.). Journal of Agronomy and Crop Science, 195: 47-54. https://doi.org/10.1111/j.1439037X.2008.00345.X

Cullis, B.R., Smith, A.B., Beeck, C.P., Cowling, W.A. 2010. Analysis of yield and oil from a series of canola breeding trials. Part II. Exploring variety by environment interaction using factor analysis. Genome, 53: 1002-1016. https://doi.org/10.1139/G10-080. 
Dadheech, R., Sharma, R., Mahla, H.R., Bhatt, R.K., 2020. Plant architecture evolution for higher yields in cluster bean (Cyamopsis tetragonoloba) under arid conditions. Indian Journal of Agricultural Sciences, 90: 79-83.

Gediya, L.N., Patel, D.A., Kumar, S., Kumar, D., Parmar, D.J., Patel, S.S., 2019. Phenotypic variability, path analysis and molecular diversity analysis in chickpea (Cicer arietinum L.). Vegetos, 32: 167-180. https://doi.org/10.1007/s42535-019-000209.

Girish, M.H., Gasti, V.D., Mastiholi, A.B., Thammaiah, N., Shantappa, T., Mulge, R., Kerutagi, M.G., 2012. Correlation and path analysis for growth, pod yield, seed yield and quality characters in cluster bean (Cyamopsis tetragonoloba (L.) Taub.). Karnataka Journal of Agricultural Sciences, 25: 498-502.

Gresta, F., Avola, G., Cannavò, S., Santonoceto, C., 2018. Morphological, biological, productive and qualitative characterization of 68 guar (Cyamopsis tetragonoloba (L.) Taub.) genotypes. Industrial Crops and Products, 114:

98-107. https://doi.org/10.1016/j.indcrop.2018.01.0 70.

Gresta, F., Cristaudo, A., Trostle, C., Anastasi, U., Guarnaccia, P., Catara, S., Onofri, A., 2018. Germination of guar (Cyamopsis tetragonoloba (L.) Taub.) genotypes with reduced temperature requirements. Aust. J. Crop Sci., 12: 954-960. https://doi: 10.21475/ajcs.18.12.06.PNE1049.

Gresta, F., Santonoceto, C., Ceravolo, G., Formantici, C., Grillo, O., Ravalli, C., Venora, G., 2016. Productive, qualitative and seed image analysis traits of guar (Cyamopsis tetragonoloba (L.) Taub). Aust. J. Crop Sci., 10: 1052-1060. https://doi: 10.21475/ajcs.2016.10.07.p7810.

Holland, J.B., Nyquist, W.E., Cervantes-Martínez, C.T. 2003. Estimating and interpreting heritability for plant breeding: an update. Plant Breeding Reviews, 22: 9-112. https://doi.org/10.1002/9780470650202.ch 2

Jaradat, A.A., 2020. Comparative assessment of einkorn and emmer wheat phenomes: IIphenotypic integration. Genetic Resources and Crop Evolution, 67: 655-684. https://doi.org/10.1007/s10722-019-008403.

Kang, M.S., 2015. Efficient SAS programs for computing path coefficients and index weights for selection indices. Journal of
Crop Improvement, 29: 6-22. https://doi.org/10.1080/15427528.2014.95 9628.

Khan, M.M.H., Rafii, M.Y., Ramlee, S.I., Jusoh, M., Al Mamun, M., 2021. Genetic analysis and selection of Bambara groundnut (Vigna subterranea [L.] Verdc.) landraces for high yield revealed by qualitative and quantitative traits. Scientific Reports, 11: 121. https://doi.org/10.1038/s41598-02187039-8.

Manivannan, A., Anandakumar, C.R., Ushakumari, R., Dahiya, G.S., 2016. Characterization of Indian cluster bean (Cyamopsis tetragonoloba (L.) Taub.) genotypes using qualitative morphological traits. Genetic Resources and Crop Evolution, 63: 483-493. doi 10.1007/s10722-015-0266-y.

Moradi, M., Soltani Hoveize, M., Shahbazi, E., 2017. Study the relations between grain yield and related traits in canola by multivariate analysis. Journal of Crop Breeding, 9: 187194.

Nampelli, P., Natarajan Seenivasan, P.P., Padmaja, V.V., 2020. Yield and yield association studies in seed guar (Cyamopsis tetragonoloba (L.) Taub.) cultivars under rainfed condition. Journal of Pharmacognosy and Phytochemistry, 9: 895898.

Papastylianou, P., Vlachostergios, D. N., Dordas, C., Tigka, E., Papakaloudis, P., Kargiotidou, A., Kostoula, S., 2021. Genotype x environment interaction analysis of faba bean (Vicia faba L.) for biomass and seed yield across different environments. Sustainability 13: 2586. https://doi.org/10.3390/su13052586.

Pathak, R., Roy, M.M., 2015. Climatic responses, environmental indices and interrelationships between qualitative and quantitative traits in cluster bean Cyamopsis tetragonoloba (L) Taub. under arid conditions. Proceedings of the National Academy of Sciences, India Section $B$ : Biological Sciences, 85: 147-154. doi 10.1007/s40011-013-0269-4.

R Core Team 2016. R: A Language and Environment for Statistical Computing. R Foundation for Statistical Computing, Vienna, Austria.

Santonoceto, C., Mauceri, A., Lupini, A., Gresta, F., Chiera, E., Sunseri, F., Anastasi, U., 2019. Morpho-agronomic characterization and genetic variability assessment of a guar germplasm collection by a novel SSR panel. Industrial Crops and Products 138, 111568. https://doi.org/10.1016/j.indcrop.2019.111 568. 
Singh, S., Devi, B., 2016. Cyamopsis tetragonoloba (L). Taub.: a phyto-pharmacological review. International Journal of Pharmacy and Pharmaceutical Research, 7: 165-174.

Sultan, M., Yousaf, M.N., Rabbani, M.A., Shinwari, Z.K., Masood, M.S., 2012. Phenotypic divergence in guar (Cyamopsis tetragonoloba L.) landrace genotypes of Pakistan. Pak. J. Bot., 44: 203-210.

Toker, C., 2004. Evaluation of yield criteria with phenotypic correlations and factor analysis in chickpea. Acta Agriculture Scandinavica, Section B-Soil and Plant Science, 54(1): 4548.

https://doi.org/10.1080/090647103100220 23.

Vir, O., Singh, A.K., 2015. Variability and correlation analysis in the germplasm of cluster bean [Cyamopsis tetragonoloba (L.) Taub.] in hyper hot arid climate of Western India. Legume Research, 37-42. doi:10.5958/09760571.2015.00006.5.

Walton, P.D., 1971. The use of factor analysis in determining characters for yield selection in wheat. Euphytica, 20: 416-421.

Yan W, Frégeau-Reid J., 2018. Genotype by Yield*Trait (GYT) Biplot: a novel approach for genotype selection based on multiple traits. Scientific Reports, 8: 8242:1-10. doi:10.1038/s41598-018-26688-8.

Yan, W., Rajcan, I., 2002. Biplot analysis of test sites and trait relations of soybean in Ontario. Crop Sci., 42: 11-20. https://doi.org/10.2135/cropsci2002.1100. 